\title{
MANDATORY CCCTB IMPLEMENTATION IN THE EUROZONE AND ITS IMPACT ON CORPORATE TAX REVENUES IN THE CZECH REPUBLIC
}

\section{Danuše Nerudová, Veronika Solilová}

\section{Introduction}

There have been many attempts to coordinate the corporate taxation systems of EU Member States. First, in 1962, the European Commission suggested splitting the corporate tax rates and applying a different tax rate for retained and distributed profits. Furthermore, eight years later, the Temple report suggested the implementation of a classical system of corporate taxation in the EU Member States. Consequently, the European Commission tried to approximate corporate tax rates - it elaborated a proposal on a common level of corporate taxation between $45 \%$ and $55 \%$ and, recently, on a minimum corporate tax rate of $30 \%$. However, because of obstacles and barriers, those harmonization efforts were not very successful. Two main obstacles to the harmonization process can be identified. First, the member states perceived a harmonization process as the effort to restrict their fiscal sovereignty than the advantage under which companies could fully benefit from the existence of the Internal Market. Second, harmonization measures need to be introduced in the form of directives that require unanimous voting, i.e., the directive has to be adopted by all EU member states. This very often resulted in the situation, in which harmonization measurement was blocked by one or two member states. Based on the findings of Ruding's Committee, the non-harmonization of corporate taxation (i.e., the existence of different taxation systems in the Internal Market) causes obstacles mainly in the form of distortion of the decisions on the investment placement of multinational corporations, as the nominal corporate tax rate represents an important decision factor. Moreover, the lack of harmonization of corporate taxation resulted in the negative harmonization through the judgments of the Court of Justice of the European Union.
Therefore, the European Commission decided to try to harmonize only the provisions affecting the smooth functioning of the Internal Market, which is understood as the main benefit of the harmonization of corporate taxation. Currently, there are many loopholes stemming from the existence of 28 national corporate taxation systems, enabling multinational corporations to apply aggressive tax-planning techniques. Harmonization of corporate tax bases therefore represents a very important tool in the fight against tax evasion and tax fraud.

As David and Nerudová added (2008), the long-term aim of the European Commission is to reduce the individual differences in the tax systems of the Member States, whether through tax harmonization or through tax coordination, in order to avoid causing obstacles to the smooth functioning of the Internal Market or the inefficient allocation of production factors or production caused by the obstacles of a tax character. Therefore, in 2001, the European Commission suggested four alternative proposals for corporate income tax harmonization - the Home State Taxation System, the European Union Company Tax, the Compulsory Harmonized Corporate Tax Base and the Common Consolidated Corporate Tax Base. After the discussion of all four models, the European Commission decided to set the implementation of the Common Consolidated Corporate Tax Base (hereinafter CCCTB) longterm. This represents one of the most ambitious projects in the history of the effort towards harmonization. The uniqueness of the project lies in the fact that, on one hand, it suggested unified rules for the construction of the tax corporate base and, on the other hand, it did not breach the national sovereignty of EU member states to independently apply the corporate tax rate. After more than ten years of work on this 
project, the Commission published the CCCTB Directive proposal on March 16, 2011.

The implementation of the CCCTB is connected not only to the grouping for taxation purposes and consolidation but also to the problem of the tax-sharing mechanism, which has raised much discussion. Finally, the directive proposal suggests the allocation formula - that the consolidated tax base should be shared among the members of the group based on micro factors. That new allocation rule had an impact on EU Member States' budgets and therefore turned out to be the most difficult part of the negotiation of the CССТВ Directive.

Therefore, the European Commission decided to re-launch the CCCTB system using the so-called step-by-step approach on June 17, 2015. This approach allowed for the introduction of the common rules for tax base construction very quickly (just the common corporate tax base without the possibility of tax consolidation), as the CCCTB was newly understood not only as a tool for the significant improvement of the business environment but also mainly as an important instrument for fair, efficient and transparent taxation within the EU. With a common tax base, all EU Member States would apply the same rules for tax base construction; therefore, structural harmonization in the area of corporate taxation would be reached. This should help EU Member States in the fight against base erosion and profit shifting, which is also addressed by the OECD and G20 in the BEPS (Base Erosion and Profit Shifting Project) project. Consequently, the second step of the consolidation regime should be introduced.

The aim of this paper is to research the impact of mandatory CCCTB implementation in the Eurozone on the tax bases and, consequently, on corporate tax revenues in the Czech Republic and to identify whether the implementation of the system will result in outflow or inflow of tax bases into the Czech Republic. The empirical analysis is based on the data available from the Amadeus and Bankscope databases. This paper presents the results of the research within the GA CR project No. 13-21683S, "The quantification of the impact of the introduction of the Common Consolidated Corporate Tax Base on the budget revenues in the Czech Republic".

\section{Literature Review}

\subsection{Harmonization of Taxation}

According to Musgrave (1967), harmonization is understood as the process of national fiscal systems' adjustment to common economic objectives. Dosser (1973) perceives tax harmonization as tax coordination between member states in the process of integration. Tax harmonization can also be understood as the process (the tools for reaching the selected aim) and the result (harmonization of tax legislation itself) together Nerudová (2014). Kubátová (1998) perceives tax harmonization as the national tax systems' adjustment and convergence under observance of the common rules. Further, the author states three phases of harmonization. First, the tax to be harmonized must be selected. Second, the harmonization of the tax base takes place, and last, the tax rate is harmonized. According to Simon (2000), total harmonization, which is reached through the three above-mentioned phases of harmonization, means that each member state applies the same taxes on the same tax base and applies the same tax rate. Thus, total harmonization is the result of the structural harmonization and harmonization of the tax rate in contrast to the partial harmonization when member states apply both common provisions and national provisions.

Under the EC Treaty in Art 93 and 94, tax harmonization is considered a tool for reaching of smooth functioning of the Internal Market. Based on it, tax harmonization can be categorized into positive and negative harmonization. As Nerudová (2014) states, positive tax harmonization represents the process of the convergence of the national tax systems of member states by the implementation of directives, regulations and other legislative tools. On the contrary, negative harmonization is the result of the activity of the Court of Justice of the European Union. Another categorization of tax harmonization, as Nerudová (2014) states, is direct or indirect harmonization. Direct tax harmonization is understood as a classical harmonization process, which tries to harmonize the regulations directly by means of tax directives. This is in contrast to indirect tax harmonization being understood as the effort to reach the harmonization of certain tax regulations by means of harmonization of different areas of law - for example, commercial law or company law - which is currently visible in the area of corporate taxation. 
In the field of direct taxation, there have been many attempts to coordinate the corporate taxation systems of EU member states. First, in 1962, the European Commission suggested splitting the corporate tax rates and applying a different tax rate for retained and distributed profits. Furthermore, in 1970, the Temple report suggested implementing a classical system of corporate taxation in the EU Member States. Consequently, the European Commission tried to approximate the corporate tax rates - it elaborated a proposal on a common level of corporate taxation between $45 \%$ and $55 \%$, most recently, on a minimum corporate tax rate of $30 \%$. Further, based on the research of Ruding's Committee, the European Commission also proposed uniform tax base rules and a maximum corporate tax rate of $40 \%$. However, those harmonization efforts were not successful; therefore, the European Commission decided to try to harmonize only the provisions affecting the smooth functioning of the Internal Market, i.e., through partial and indirect harmonization.

Therefore, there is not an integrated European tax system in the European Union, but rather a junction of different national tax systems, which increases the compliance costs of taxation. As Hitris (1994) states, the situation in the European Union fully corresponds to the fiscal divergence - there is no rapprochement, which is defined as the situation in which all the member states apply the same tax system. The harmonization process that aimed to reach a unified taxation system (through the total direct harmonization of national tax systems) turned into the convergence and approximation of the taxation systems, as Hitiris (1994) and Kubátová (1998) state.

In 2001, in respect to the high sensitivity of investments to the differences in the corporate taxation and the fact that the tax systems should be neutral, the European Commission proposed four possible models of corporate income tax harmonization, namely, Home State Taxation (corporations adopt the taxation of companies with "European" activities the rules valid in the home country in which the headquarters is situated), CCCTB (supposes the existence of the common rules for tax base constructions), European Union Company Tax (large multinational corporations use the uniform consolidated tax base and unified corporate income tax rate within the EU) and Compulsory Harmonized Corporate Tax Base (this system would introduce the uniform tax base for every company in the EU). At first, the European Commission chose a twin-track strategy with a long-term target in the form of CCCTB for corporations with European activities, but ultimately, the European Commission decided to set only the implementation of the CCCTB. After more than ten years of work, the Commission published the CCCTB Directive proposal on March 16, 2011.

Tax harmonization is still facing many obstacles and barriers. The most serious obstacle can be considered the political barrier ensuing from the unwillingness to harmonize tax provisions, which can cause obstacles to smooth the functioning of common market or market deformations. EU member states perceived a harmonization process as the effort to restrict their fiscal sovereignty. Moreover, harmonization measures must be introduced by the European Commission in the form of a directive to be legally binding for all EU member states, which represents the second serious barrier to complete full harmonization.

Tax harmonization may also bring some cons. It leads to a higher tax rate because, without competition, governments may establish higher taxes, i.e., tax harmonization does not create pressure on the expenditure side of budgets. Tax harmonization may therefore also lead to lower economic growth, for higher tax rates decrease productivity and discourage foreign capital. Moreover, tax harmonization does not prevent the oversized expansion of the public sector. Further, it restricts the fiscal sovereignty of the EU Member States, as mentioned above, and can significantly endanger the budget revenues of the Member States applying higher tax rates than when harmonized.

In contrast, tax harmonization may bring several pros, such as the elimination of the risk of double taxation, the elimination of base erosion and profit shifting mainly through the migration of national tax bases to the countries with more favorable tax regimes. Tax harmonization also eliminates tax arbitrations arising from the existence of different tax regimes. It can further remarkably decrease compliance costs of taxation and may help to establish fair tax competition (within the meaning that all actors on the market do have the same information about the tax rate). Moreover, companies in the Internal Market may fully exploit the connected advantages. 
In June 2015, as a reaction to the base erosion and profit shifting EU Member States are currently facing in the area of corporate taxation in the EU, the European Commission introduced the Action Plan for Fair and Efficient Corporate Taxation, announcing the re-launch of the CCCTB system to the common corporate tax base (hereinafter CCTB) system, i.e., from the common consolidated corporate tax base towards the common corporate tax base without the consolidation regime. This approach allows us to introduce first the CCTB rules and, second, the consolidation regime. Moreover, the CCTB system should be introduced as a mandatory system because the existence of two different taxation systems for corporations within the EU (i.e., CCTB or CCCTB recently and the national tax system), could open the space for speculations, tax fraud and various types of tax arbitrations. Interestingly, the CCTB (СССТВ) could serve not only as a tool for the significant improvement of the business environment but also as a powerful tool against corporate tax avoidance, which can make corporate taxation in the EU much more transparent and can help to decrease aggressive tax planning. In addition, according to the European Commission, CCTB also represents a framework for the implementation of many of the new standards agreed on through OECD in the BEPS project. In this respect, the European Commission presented the Anti-Tax Avoidance Directive as part of the Anti-Tax Avoidance Package on January 28, 2016.

\subsection{Sharing Mechanism}

The implementation of the consolidation regime is indivisibly connected to the need for the implementation of the mechanism for the sharing of the group tax base among Member States. The taxation theory offers several mechanisms for the sharing of the tax base. Some have already been implemented, e.g., in the USA and Canada.

The factors employed in the mechanism for sharing the tax base can be divided into formulary apportionment based on macrofactors (usually aggregated at the national level - i.e., for example GDP or national VAT tax base) and microfactors. As mentioned by Lodin and Gammie (2001), the selection of the individual method of formulary apportionment, as well as the selection of factors, significantly influences the size of the allocated group tax base. The taxation theory offers two possible methods in the case of formulary apportionment with microfactors - Value Added Methods (hereinafter VA) and an Allocation Formula (hereinafter FA).

A parallel can be found between the VA method and the methods of the determination of company value added. As in the case of company value added, the VA method can be based on adding principle and subtracting principle.

The value added of the group member for taxation purposes with the application of the subtracting principle is calculated as follows:

$$
V A=T V O-T V I
$$

where TVO represents total value of outputs and $T V I$ the total value of inputs.

The value added of the group member for taxation purposes with the application of the adding principle is determined as follows:

$$
V A=L C+I+P
$$

where $L C$ represents labor compensation, $I$ stands for interests and $P$ represent profits.

Considering this formulary apportionment as a sharing mechanism for the group tax base, it is necessary to take into account the territory dimension of the method and to determine the state in which the value added was created - whether in the member state in which the goods were produced or in the member state in which the goods were sold. Based on this, the tax theory differs between the destinationbased VA method (i.e., the method under which the value added is created in the member state where the goods are sold) and the origin-based VA method (i.e., the method under which the value added is created in the member state where the goods were produced).

In the CCCTB situation, the VA would be employed for the allocation of the group tax base, and the share of the total value of the group would be determined as follows:

$$
T B_{i}^{V A}=C T B\left(\frac{V A_{i}}{\sum_{i}^{n} V A_{i}}\right) \times 100
$$

where $T B_{i}^{V A}(\mathrm{i}=1, \ldots \mathrm{n})$ represents all jurisdictions where the group is active) is the share of the 
jurisdiction on the group tax base, allocated based on the value added. Based on the abovestated allocation formula, the consolidated group tax base would be allocated amongst the corporations operating in individual member states based on their share on total value added of the group, as previously mentioned in the literature (Agúndez-García, 2006).

Formulary apportionment represents the tool traditionally used for tax base sharing in the USA and Canada. The history of formulary apportionment in the USA goes back to the 1870s, where it had been first applied in the area of property taxation. As mentioned in the literature (Weiner, 2005), instead of measuring a company's property in an individual state, the companies measured their property, and the tax base was distributed to individual states based on the share of railways in each individual state. For income taxation purposes, the FA was first applied in Wisconsin. At the end of the 1930s, nearly all companies already applied the three-factor formula with equally weighted factors. This formula is known as the Massachusetts Formula in taxation theory and can be expressed as follows:

$$
P_{i}=P_{t}\left(\frac{1}{3} \frac{C_{i}}{C_{t}}+\frac{1}{3} \frac{L_{i}}{L_{t}}+\frac{1}{3} \frac{S_{i}}{S_{t}}\right)
$$

where $P_{i}$ represents the profit allocated to the state $i, P_{t}$ is the profit of the companies, $C$ stands for capital and $S$ represent sales. As mentioned in the literature (Mayer, 2009), since the 1980s, states have moved from equally weighted factors towards the allocation formula, where higher weight is put on the sales factor, while the weight in the case of payroll and capital was decreased.

The development of allocation mechanism in Canada has been slightly different from its development in the USA. As mentioned by Weiner (2005), originally, the allocation rules allocated income to the state where the permanent establishment of the company was situated. If the company possessed a permanent establishment in more provinces, income was allocated based on the company's accounting or according to the share of the permanent establishment in the total income of the company. As mentioned in the literature (Mintz, 2004), while this system was widely criticized, the discussion of the possible implementation of the US model raised fears that it could allocate too much income to the exporting provinces. Therefore, the FA was modified to a two-factor formula with equally weighted factors. The Canadian formula can be expressed as follows:

$$
P_{i}=P_{t}\left(\frac{1}{2} \frac{G I_{i}}{G I_{t}}+\frac{1}{2} \frac{L_{i}}{L_{t}}\right)
$$

where $P_{i}$ represents the profit allocated to the province $i, P_{t}$ is the profit of the companies, $G I_{t}$ represents the gross income of the company, and $L$ is labor. The main difference between the US FA and the Canadian FA lies in the fact that federal allocation rules comprise specific rules for specific industry sectors - e.g., the insurance industry or road transportation.

According to Petutschnig (2010), the mostused factors represent payroll, capital and sales. These factors are used in the allocation formulae in different combinations and with different weights. The allocation formula suggested in the CCCTB system comprises three equally weighted factors - sales, labor and assets. As is obvious from the belowstated equation, the labor factor consists of two equally weighted factors - payroll and the number of employees. The allocation formula can be expressed as follows:

$$
\begin{aligned}
& \text { ShareX }=\left(\frac{1}{3} \frac{S^{A}}{S^{\text {group }}}+\frac{1}{3}\left(\frac{1}{2} \frac{P^{A}}{P^{\text {Group }}}+\right.\right. \\
& \left.\left.+\frac{1}{2} \frac{E^{A}}{E^{\text {Group }}}\right)+\frac{1}{3} \frac{A^{A}}{A^{\text {Group }}}\right) * C C C T B
\end{aligned}
$$

where $S$ represents the sales of goods and services, $P$ is payroll (comprising wages and salaries, bonuses and other compensation), $E$ represents the number of employees (employed for the period of 3 months at least) and $A$ are assets (including fixed assets, buildings, aircraft, boats and machines).

\subsection{The Effects of the CССТВ Implementation}

The implementation of CCCTB can be connected to the advantages for the corporations and for tax administrations. The transparency of the effective tax rate and harmonization 
rules for tax base construction should lead to the establishment of the fair tax competition (meaning the situation in which all market subjects have the same information about the effective tax rate) and to the elimination of tax obstacles of mergers and acquisitions mainly in the areas of capital profit taxation, reduced compliance costs of taxation, the elimination of transfer pricing issues, and the establishment of the possibility of cross-border loss offsetting. Because the proposal of the CCCTB represents one of the most ambitious projects in the history of taxation, it initiated extensive scientific work, which can be categorized into the three main streams. The first of them is to focus on the overall general concept of the CCCTB system and its implementation into national systems (Riedel \& Runkel, 2006; Mintz, 2008; McLure, 2008; Bettendorf et al., 2010; Trandafir, 2011; Dankó, 2012, and others). Mintz (2008), for example, highlights both imposing its own tax rates to avoid any disruption of the fiscal sovereignty and direct control of tax revenues and tax administration, in contrast to Bettendorf et al. (2010), who states that the most effective redistribution of capital, tax revenues and welfare will be reached through the CCCTB and the uniform tax rate. Further, Riedel and Runkel (2006) underline the positive fiscal externality in the short-term CCCTB, but in the case of long-term CCCTB, they recommend the implementation of the uniform tax rate.

The second stream of the research aims at the analysis of allocation formula factors with respect to the prediction of corporate income (Pethig \& Wagener, 2003; Agúndéz-Garcia, 2006; Mintz, 2008; Tan, 2010; Roggeman et al., 2012; Krchnivá, 2014; Krchnivá \& Nerudová 2015; Cobham \& Loretz, 2014; Eberhartinger \& Petutschning, 2014, and others). According to Agúndéz-Garcia (2006), the most discussed allocation-formula factor is represented by assets due to the mobility of capital and investments. Further, Mintz (2008) considers the most easily measured allocation-formula factor to be employees' costs. Eberhartinger and Petutschning (2014) add that, based on the number of employees, the payroll formula factor can be used to analyze the impacts of different levels of employees' costs in EU member states on the allocation of consolidated corporate tax profit. Roggeman et al. (2012) prove that the European Commission proposed allocationformula factors to explain the corporate tax profit in the amount of $28 \%$. This similar result was also found by Krchnivá and Nerudová (2015). According to her, the proposed CCCTB formula factors are able to explain almost $35 \%$ of the variability in profitability of the Czech companies, in contrast to Hines (2010), whose allocation-formula factors (the sales, assets and payroll of the U.S. companies) are able to explain almost $50 \%$ of the variability in profitability. Furthermore, Krchnivá (2014) proves that the presence or proportion of allocation-formula factors can significantly affect a country's overall tax revenues. Cobham and Loretz (2014) state that the allocation of corporate tax profit based on the tangible assets and number of employees is beneficial in the case of low-income countries, in contrast to the high-income countries, for which sales and costs of employees are more beneficial factors.

The third stream of research focuses on the impacts of the introduction of the CCCTB system on tax revenues (Fuest, Hemmelgarn, \& Ramb, 2007; Van der Horst, Bettendorf, \& Rojas-Romagosa, 2007; Devereux \& Loretz, 2008; Cline et al., 2010; Domonkos, Domonkos, Dolinajcová, \& Grisáková, 2013; Nerudová \& Solilová, 2015, and others). Only a few empirical studies research the impact of the introduction of the CCCTB on the budget revenues of EU Member States. Unfortunately, none of the studies focuses on the scenario that the CCСTB will be implemented through enhanced cooperation (i.e., not by all EU Member States).

The paper by Fuest, Hemmelgarn and Ramb (2007) simulated the scenario of mandatory CCCTB. It is based on the data on German company-level foreign direct investment and data from balance sheets. These authors use the smallest dataset for their research $-2,000$ German parent companies and 6,000 foreign subsidiaries in other EU Member States between 1996 and 2000. Based on the results of the research, the authors estimate that national tax bases would decline by $20 \%$ on average.

Furthermore, the paper by Van der Horst, Bettendorf \& Rojas-Romagosa (2007) also simulated the scenario of mandatory CCCTB. However, the authors perform the research in $17 \mathrm{EU}$ Member States. It is necessary to mention that the budgetary impacts were not the main research question. The paper aims 
primarily at the welfare effects connected with the introduction of the system. This study also assumes that all companies have to opt for the CCCTB. This research is based on the equilibrium model, which expects that each of the $17 \mathrm{EU}$ Member States has a parent company with subsidiaries in each of the remaining Member States. They conclude that the obligatory implementation of the CCCTB in $17 \mathrm{EU}$ Member States would result in an increase in welfare of $0.02 \%$ of GDP.

The paper by Deveraux and Loretz (2008) represents a more complex study. The paper researches two scenarios - voluntary and mandatory CCCTB. The research is based on a large dataset of 50,000 companies during the period in the years 2000-2004. The research revealed that under a voluntary system, tax revenues could decrease by $2.5 \%$, while under a mandatory system, revenues could increase by $2 \%$. It is important to mention that this study also proved that the effect on the budget revenues of individual Member States would be unequal, for it varies from $-18 \%$ to $+60 \%$.

The most recent and last study by Cline et al. (2010) researched three possible scenarios - mandatory CCCTB in all EU Member States, voluntary CCCTB in all EU Member States and mandatory CCCTB in 9 EU Member States. The study is built on the largest dataset so far - on a model of 200,000 companies in the year 2005. The scenario of a mandatory CCCTB system in 27 Member States also revealed that there would be unequal impacts, that is, that there would be winners and losers. The effect on corporate income tax collection varied from $-8.3 \%$ in Denmark to $+6.0 \%$ in France. It is necessary to mention that this study represents the only study to predict the effects on the budget of the Czech Republic. Under the mandatory implementation of the CCCTB, the Czech Republic would lose $3.0 \%$ of corporate tax collection. In the case that the system was voluntary in 27 Member States, the range of changes would be narrower - from $-7.7 \%$ in Germany to $+2.6 \%$ in the United Kingdom. The Czech Republic would lose roughly the same - i.e., $-3.1 \%$ of corporate tax collection. The scenario of mandatory CCCTB in 9 Member States revealed that the change in corporate tax collection would vary from $-8.5 \%$ in the Netherlands to $+5.7 \%$ in France.

The impact of CCCTB implementation in the EU28 on the budgetary revenues of selected countries only was researched by Nerudová and Solilová (2015) and Solilová and Nerudová (2016) for the case of the Czech Republic. A study researching the impact of CCCTB implementation on the budget revenues in the Slovak Republic was conducted by Domonkos, Domonkos, Dolinajcová and Grisáková (2013). Another study by Pirvu et al. (2011) researched the impact of CCCTB implementation on tax revenue in Romania.

\section{Data and Methodology}

The research is based on the data from the Amadeus database (update 227), which includes standardized financial information on more than 18 million public and private companies in 43 European countries, as well as on current studies by Devereux and Loretz (2008), Fuest, Hemmelgarn and Ramb (2007) and Clien et al. (2010). Moreover, our research covers data from the Bankscope database (updated in January 2014) including information on over 32,000 banks, public and private, and the leading 35 supranational banking and financial organizations from all over the world. Specifically, the top 8,000 European banks, the top 14,000 North American banks, 1,000 Japanese banks, 1,200 Russian banks, over 7,000 other major banks and the leading 35 supranational banking and financial organizations.

With respect to the aim of this paper, it was necessary to obtain from the databases the group of the Czech companies and other EU companies with a connection to the Czech Republic (i.e. having subsidiaries in the Czech Republic) that would qualify under the CCCTB system for the consolidation regime and group treatment. For this purpose, we followed the approach of the proposal of the CCCTB Directive and performed a two-tiered test. This test consists of two layers: control, which is assumed if the controlling company holds at least $50.01 \%$ of the controlled company, and ownership, which is assumed if the ownership rights amount to more than $75 \%$ of the company's capital.

From the Amadeus database, based on the two-tiered test, 1,587 Czech parent companies with 2,427 subsidiaries in the Czech Republic and other EU Member States, and 816 other EU parent companies with 1,135 subsidiaries in the Czech Republic were identified. From the Bankscope database, based on the 
two-tiered test, 10 Czech parent companies with 49 subsidiaries in the Czech Republic and other EU Member States and 11 other EU parent companies with 249 subsidiaries in the Czech Republic were identified. The overall number of companies, specifically 2,424 parent companies with 3,860 subsidiaries, represents final dataset with all necessary data.

However, given this overall number of companies, we faced the problem of missing information in the financial statements of some companies. In order to preserve the extent of the dataset, we followed the approach of Clien et al. (2010) and decided to impute missing information in order to maximize the number of companies in the analysis. Therefore, we performed a sensitivity analysis, employing three missing data methods, i.e., regression, imputation and multiple imputation, for the selection of the best method for data imputation to avoid significantly distorting the allocation of the CCCTB between the EU Member States. Based on the obtained results, the method of imputation was selected, using reported tangible fixed assets and the industry-specific ratio of the individual apportionment factor (namely payroll, the number of employees and operating revenues representing sales) to tangible fixed assets for companies in the same NACE sector of the economy [for details, see Nerudova \& Solilova (2014)]. Specifically, the following formulae were used for the imputation of missing data:

Missing operating revenue amounts were imputed using reported tangible fixed asset data (TFA_reported) and the ratio of observed average operating revenue (AOperR) to the tangible fixed assets for other companies in the same industry (ATFA):

$$
\begin{aligned}
& \text { Operating_revenue }= \\
& =(A O p e r R \div A T F A) * T F A \_r e p o r t e d
\end{aligned}
$$

The missing number of employees was imputed based on the reported tangible fixed assets of the company and the ratio of observed average numbers of employees (ANoE) to tangible fixed assets for the other companies in the same industry:

$$
\begin{aligned}
& \text { No.Employees_imputed }= \\
& =(A N o E \div A T F A) * T F A \_ \text {reported }
\end{aligned}
$$

Missing payroll data were imputed based on the imputed employee headcount (No. Employees_imputed) and the ratio of observed average payroll cost (APayr) to employee headcounts for other companies in the same industry:

$$
\begin{aligned}
& \text { Payroll }=(\text { APayr } / \text { ANoE }) * \\
& \text { * No.Employees_imputed }
\end{aligned}
$$

Furthermore, because Eastern European countries have lower levels of apportionment factors, mainly payroll, the industry-specific ratios were calculated separately for Eastern Europe and Western Europe.

Subsequently, in order to determine the Czech tax base according to current conditions, the group taxation schemes and consolidation schemes in individual EU Member States needed to be researched. Based on the research (Nerudova, 2012), the EU Member States can be divided into four groups according to the applied consolidation or group taxation rules - full consolidation (in Netherlands), pooling of the result on the parent company (in Denmark, Germany, Spain, France, Italy, Luxembourg, Austria, Poland, Portugal), intra-group loss transfer (in Ireland, Cyprus, Malta, Lithuania, Latvia, Sweden, Finland, United Kingdom) and the group where no group taxation scheme is available (in Belgium, Bulgaria, Croatia, Czech Republic, Greece, Hungary, Slovak Republic, Estonia, Romania and Slovenia). The fourth group of states covers 10 EU Member States for which it can be considered that the CCCTB will represent the most attractive tool for addressing the possibility that group taxation and loss offset within the group.

Based on the above-mentioned categorization, the total tax base of each of the groups from the dataset $(2,424$ parent companies with 3,860 subsidiaries in the $\mathrm{EU}$ ) was determined, where the profit or loss before taxation was considered as an indicator of the individual tax base of each subsidiary. After that, the determination of the total allocated tax base of the Czech Republic was performed, the assumptions of potential outflow/inflow of tax bases from/into the Czech Republic were set up as a consequence of the implementation of the CCCTB system in the Eurozone. In 2015, the Eurozone consists Member States such as Austria, Belgium, Estonia, Finland, France, Ireland, Italy, Luxembourg, Latvia, Netherlands, 
Portugal, Slovakia, Spain, Greece, Slovenia, Cyprus, Malta and Lithuania.

The first basic assumption is based on the fact that the differences in corporate taxation, differences in the level of effective corporate tax rates among EU Member States and the burden of corporate taxes have an impact on corporations' decision regarding the location of their economic activity, as proven by the Commission of European Communities (1992). This factor was also identified in the research by Kolářová and Kuderová (2015), which was specifically focused on companies in the Czech Republic. Based on this, Dischinger (2007) concluded that the profit of the subsidiary decreases by $7 \%$ if the difference in the corporate tax rate of the subsidiary to its parent company increases by 10 percentage points. Further, there is a stream of literature supporting the idea that multinational groups have an incentive to shift incomes. De Mooij and Ederveen (2008) state that multinational group shifts profits to low tax jurisdictions and expenses to high tax jurisdictions. Moreover, Mackie-Mason and Gordon (1997) and Bartelsman and Beetsma (2003) emphasize that the corporate tax rate represents a key determinant of profit shifting.

Therefore, the potential outflow/inflow of tax bases from/into the Czech Republic would occur in accordance with the level of effective tax rates in the Eurozone. We assume that the potential outflow/inflow of tax bases would occur if parent companies with Czech subsidiaries were situated in the Member States of the Eurozone with a lower effective tax rate than in the Czech Republic. As is obvious from Tab. 1 below, the countries applying an effective tax rate lower than in the Czech Republic are Cyprus, Estonia, Ireland, Latvia, Lithuania and Slovenia.

\begin{tabular}{c|c|c|c|c|c} 
Tab. 1: & $\begin{array}{c}\text { Nominal corporate tax rate and effective average tax rate by Member States of } \\
\text { Eurozone and by the Czech Republic, 2014 }\end{array}$ \\
Country & $\begin{array}{c}\text { Corporate tax } \\
\text { rates in \% }\end{array}$ & $\begin{array}{c}\text { Effective } \\
\text { average tax rate } \\
\text { in \% }\end{array}$ & Country & $\begin{array}{c}\text { Corporate tax } \\
\text { rates in \% }\end{array}$ & $\begin{array}{c}\text { Effective } \\
\text { average tax } \\
\text { rate in \% }\end{array}$ \\
\hline CZ & 19.0 & 16.7 & IT & 30.9 & 24.0 \\
\hline AT & 25.0 & 23.0 & LV & 15.0 & 14.3 \\
\hline BE & 34.0 & 26.7 & LT & 15.0 & 13.6 \\
\hline CY & 12.5 & 15.2 & LU & 29.2 & 25.5 \\
\hline EE & 21.0 & 16.5 & MT & 35.0 & 32.2 \\
\hline FI & 20.0 & 18.4 & NL & 25.0 & 22.6 \\
\hline FR & 38.9 & 39.4 & PT & 30.0 & 27.1 \\
\hline DE & 31.0 & 28.2 & SK & 22.0 & 19.4 \\
\hline EL & 26.0 & 24.1 & SI & 17.0 & 15.5 \\
\hline IE & 12.5 & 14.4 & ES & 35.3 & 32.6 \\
\hline
\end{tabular}

Source: Spengel, Endres, Finke and Heckemeyer (2014).

Furthermore, according to the research by Grubert and Slemrod (1998), income shifting is very often connected with real investments. Therefore, with respect to Czech parent companies, we assume that potential outflow/ inflow of tax bases would occur if the Czech parent company has at least one subsidiary situated in the Eurozone (i.e., we do not expect that a group with only Czech subsidiaries would move its tax bases from the Czech Republic) when the CCCTB system is implemented.

The second assumption is based on the key findings by Fuest et al. (2013) that multinational group performs their activities and profit shifting with the aim to minimize the overall tax burden. Therefore, it is assumed that the group of companies qualified under the CCСTB system for the consolidation regime would bear a lower 
tax burden after the implementation of the CCCTB system in the group.

Furthermore, we assume that outflow from the Czech Republic would occur into a Eurozone country where the subsidiary or parent company from the group is situated, as supported by the research by Grubert and Slemrod (1998). In the case of a higher number of subsidiaries in different Member States of the Eurozone, selection is based on the nominal corporate tax rate (i.e., outflow would be into the country with the lowest corporate tax rate), as assumed by Mackie-Mason and Gordon (1997) and Bartelsman and Beetsma (2003). Moreover, the second scenario also expects the outflow of the tax base of the Czech parent company in order to reach the possibility of entering into the CCCTB system, which is also assumed by Fuest et al. (2013).

The last assumption made is that only companies operating in the industry or providing services (based on the NACE code) that can be relocated outside the Czech Republic are considered (in tables presented as situation B) because not all types of businesses can relocate easily into a jurisdiction with a better tax environment (Nerudová \& David, 2008).

However, as mentioned by Avi-Yonah \& Clausing (2007), this kind of re-distributional effect and its prediction depends on various future behavioral effects, which are very difficult to foresee. It can be expected that, based on the allocation-formula factors used in the CCCTB system, tax havens and countries without real substance of business activities can reach a reduction of tax revenues, in contrast to real economies with an increase in tax revenues.

The determination of the potential outflow/ inflow of tax bases from/into the Czech Republic is based on the comparison of the current and new tax burdens of each group. In the case of the current situation, the effective tax rates (see Tab. 1 above) of the country where subsidiaries are situated were taken into account in order to determine the tax liability (as a tax base was considered profit or loss before taxation of each subsidiary in the group). When researching the situation of CCCTB implementation, the nominal tax rates were applied because, under the CCCTB, nominal tax rates are equal to the effective ones due to the unified system of tax base construction (for the nominal tax rate, see Tab. 1 above). The nominal tax rate was used on the portion of the group tax base under the CCCTB system, which was allocated to the individual group members based on the allocation formula (6).

Moreover, in accordance with the CCCTB proposal, the special allocation formula for financial and insurance activities (i.e., NACE sector $\mathrm{K}$, dataset from Bankscope) was considered. In the case of financial institutions (financial institutions are (a) credit institutions authorized to operate in the Union in accordance with Directive 2006/48/EC of the European Parliament and of the Council; (b) entities, except for insurance undertakings as defined in Article 99, which hold financial assets amounting to $80 \%$ or more of all their fixed assets, as valued in accordance with the rules of this Directive) and insurance undertakings (insurance undertakings mean those undertakings authorized to operate in the Member States in accordance with Directive 73/239/EEC for non-life insurance, 2002/83/EC for life insurance and Directive 2005/681EC for reinsurance), the asset factor includes $10 \%$ of the value of financial assets, except for participating interests and own shares. Furthermore, the sales factor of a financial institution includes $10 \%$ of its revenues in the form of interest, fees, commissions and revenues from securities, excluding value added tax, other taxes and duties. The sales factor of insurance undertakings includes $10 \%$ of all earned premiums, net of reinsurance, allocated investment returns transferred from the nontechnical account, other technical revenues, and investment revenues, fees and commissions, excluding value added tax, other taxes and duties.

As mentioned above (in the second assumption), only groups bearing a lower tax burden in the case of the CCCTB system would relocate their tax bases (i.e., their taxable presence) out of the Czech Republic. In addition, it is necessary to mention that the research does not take into account any barriers to entry or exit, as we assume relocation into the country where the parent or other subsidiary is situated. However, the sensitivity analysis was performed when the different levels of the transaction costs were taken into account in the amount of $1 \%, 5 \%$ and $10 \%$ of the group tax burden based on the current situation.

\section{Results}

This study simulated the implementation of the CCCTB system in the Eurozone for the total 
group of companies $(2,424$ parent companies with 3,860 subsidiaries) obtained from the Amadeus and Bankscope databases under the above-mentioned assumptions. The Amadeus dataset covered the group of the Czech parent companies having subsidiaries with a taxable presence in member states of the Eurozone such as Austria, Slovakia, Estonia, Germany, and the Netherlands and in Non-Member States such as Poland, United Kingdom and Hungary. In contrast to the Bankscope dataset, which classified subsidiaries of Czech parent companies in Slovenia, Belgium, Slovakia and the Netherlands (as a member state of the Eurozone) and in the United Kingdom (as a non-member state of the Eurozone). Those identified Eurozone states would receive the tax bases of the Czech subsidiaries and eventually of the Czech parent companies, if both the implementation of the CCCTB system brought the lower tax liability to the group and the relocation of business activities outside the Czech Republic was possible. In contrast, the Amadeus dataset covering the group of other EU parent companies with Czech subsidiaries having parent companies located in the member states of Eurozone, where the corporate tax rate is lower than in the Czech Republic (i.e., Cyprus, Ireland, Slovenia and Lithuania). The Bankscope dataset does not include any parent companies in the member states of the Eurozone with a lower corporate tax rate than in the Czech Republic; therefore, no outflow of tax bases is expected in case of the Czech subsidiaries.

The research identified that, if the implementation of the CCCTB system in the Eurozone were to occur, there would be potential outflow of tax bases of 40 Czech subsidiaries, their 12 Czech parent companies, and 20 Czech subsidiaries of other EU parent companies from the Amadeus dataset. Additionally, the research identified the potential outflow of tax bases of 33 Czech subsidiaries and their 6 Czech parent companies from the Bankscope dataset. As seen from Tab. 2 below, the largest outflow is in the group of Czech parent companies and their subsidiaries. In total, the outflow of 93 Czech subsidiaries and 18 Czech parent companies is expected after the implementation of the CCCTB system in the Eurozone. The research has not identified any inflow of tax bases.

The impact of the implementation of the CCCTB in the Eurozone on the tax bases allocated in the Czech Republic and subsequently on the Czech corporate tax revenues is presented in Tabs. 3 and 4 below. As seen in Tab. 3, the group of Czech parent companies and their subsidiaries generates the corporate tax base in the amount of EUR $1,655,877,000$ in the Czech Republic. The research identified the potential outflow in this group in the amount of EUR 426,453,000 (i.e., almost $26 \%$ of the current tax base allocated by this group in the Czech Republic). The largest outflow is expected in NACE sector K - Financial and insurance activities (99\%). However, if the possibility of the relocation of the business activities is considered (situation $B)$, then the potential outflow is expected in the amount of EUR $11,879,000$ (i.e., only $0.72 \%$ of the current tax base). As we consider the NACE sector $K$ covering activities of financial institutions (mainly banks) as a non-relocated business activity. Moreover, the outflow of the tax bases of Czech parent companies is also

\section{Tab. 2: Summary of parent companies and its subsidiaries and their potential outflow}

\begin{tabular}{|c|c|c|c|c|c|c|c|c|c|c|}
\hline \multirow{3}{*}{ Database } & \multicolumn{4}{|c|}{ Czech parent companies } & \multicolumn{4}{|c|}{ Other EU parent companies } & \multirow{3}{*}{ 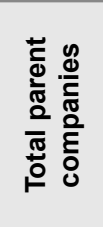 } & \multirow{3}{*}{ 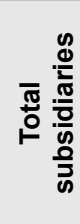 } \\
\hline & \multicolumn{2}{|c|}{$\begin{array}{l}\text { No. of parent } \\
\text { companies }\end{array}$} & \multicolumn{2}{|c|}{$\begin{array}{c}\text { No. of subsidi- } \\
\text { aries in EU }\end{array}$} & \multicolumn{2}{|c|}{$\begin{array}{l}\text { No. of parent } \\
\text { companies }\end{array}$} & \multicolumn{2}{|c|}{$\begin{array}{l}\text { No. of subsidi- } \\
\text { aries in } \mathrm{CZ}\end{array}$} & & \\
\hline & Total & $\begin{array}{l}\text { Out- } \\
\text { flow }\end{array}$ & Total & $\begin{array}{l}\text { Out- } \\
\text { flow }\end{array}$ & Total & $\begin{array}{l}\text { Out- } \\
\text { flow }\end{array}$ & Total & $\begin{array}{l}\text { Out- } \\
\text { flow }\end{array}$ & & \\
\hline Amadeus & 1,587 & 12 & 2,427 & 40 & 816 & 0 & 1,135 & 20 & 2,403 & 3,562 \\
\hline Bankscope & 10 & 6 & 49 & 33 & 11 & 0 & $2 \pi$ & 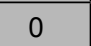 & 21 & 298 \\
\hline Total & 1,597 & 18 & 2,476 & 73 & 827 & 0 & 1,384 & 20 & 2,424 & 3,860 \\
\hline
\end{tabular}




\begin{tabular}{|c|c|c|c|c|c|c|}
\hline \multirow{3}{*}{ NACE$^{1}$} & \multicolumn{4}{|c|}{$\begin{array}{c}\text { Tax bases of Czech subsidiaries of the Czech } \\
\text { parent companies }\end{array}$} & \multicolumn{2}{|c|}{$\begin{array}{l}\text { Expected outflow - parent } \\
\text { companies }\end{array}$} \\
\hline & \multirow{2}{*}{$\begin{array}{c}\begin{array}{c}\text { Current tax } \\
\text { base }\end{array} \\
\text { in th. EUR }\end{array}$} & \multicolumn{2}{|c|}{$\begin{array}{l}\text { Expected outflow } \\
\text { of tax base }\end{array}$} & \multirow{2}{*}{$\begin{array}{c}\begin{array}{c}\text { Expected } \\
\text { outflow of } \\
\text { tax liability }\end{array} \\
\text { in th. EUR }\end{array}$} & Tax base & Tax liability ${ }^{a}$ \\
\hline & & $\%$ & in th. EUR & & \multicolumn{2}{|c|}{ in th. EUR } \\
\hline A & 1,663 & - & - & - & - & - \\
\hline B & 7,836 & - & - & - & - & - \\
\hline C & 110,250 & 0.08 & 378 & 63 & 20,053 & 3,349 \\
\hline D & 245,368 & - & - & - & 296 & 50 \\
\hline$E$ & 12,955 & - & - & - & - & - \\
\hline$F$ & 8,565 & - & - & - & - & - \\
\hline G & 341,386 & 0.08 & 356 & 60 & 10,521 & 1,757 \\
\hline $\mathrm{H}$ & 21,084 & - & - & - & - & - \\
\hline I & 1,813 & - & - & - & - & - \\
\hline $\mathbf{J}$ & 44,540 & - & - & - & - & - \\
\hline $\mathrm{K}^{2}$ & 205,203 & 2.58 & 11,032 & 1,843 & 187 & 31 \\
\hline $\mathrm{K}^{3}$ & 416,579 & 97.21 & 414,574 & 70,721 & $1,746,359$ & 291,642 \\
\hline $\mathbf{L}$ & 53,897 & - & - & - & - & - \\
\hline$M$ & 93,671 & 0.03 & 113 & 19 & 153,331 & 25,606 \\
\hline $\mathbf{N}$ & 3,996 & - & - & - & - & - \\
\hline 0 & 73,767 & - & - & - & - & - \\
\hline $\mathbf{P}$ & 557 & - & - & - & - & - \\
\hline $\mathbf{Q}$ & 2,376 & - & - & - & - & - \\
\hline $\mathbf{R}$ & 10,347 & - & - & - & - & - \\
\hline S & 25 & - & - & - & - & - \\
\hline \multirow[t]{2}{*}{ Total ${ }^{b}$} & $1,655,877$ & $100 \%$ & 426,453 & 70,706 & $1,930,747$ & 322,435 \\
\hline & $100 \%$ & & $25.76 \%$ & & & \\
\hline \multirow[t]{2}{*}{ Total $\mathbf{B}^{\mathrm{c}}$} & $1,655,877$ & & 11,879 & 1,985 & 184,092 & 30,743 \\
\hline & $100 \%$ & & $0.72 \%$ & & & \\
\hline
\end{tabular}

Source: Own research and Amadeus and Bankscope databases

Note:

1) A - Agriculture, forestry and fishing, B - Mining and quarrying, C - Manufacturing, D - Electricity, gas, steam and air conditioning supply, E - Water supply; sewerage; waste management and remediation activities, F - Construction, $\mathrm{G}$ - Wholesale and retail trade; repair of motor vehicles and motorcycles, $\mathrm{H}$-Transporting and storage, I-Accommodation and food service activities, $\mathrm{J}$ - Information and communication, $\mathrm{K}$ - Financial and insurance activities, $\mathrm{L}-\mathrm{Real}$ estate activities, $\mathrm{M}$ - Professional, scientific and technical activities, $\mathrm{N}$ - Administrative and support service activities, $\mathrm{O}$ - Public administration and defense; compulsory social security, P - Education, Q - Human health and social work activities, $\mathrm{R}$ - Arts, entertainment and recreation, $\mathrm{S}$ - Other services activities.

2) NACE $K$ includes only data from the Amadeus database, considering financial and insurance companies.

3) NACE K includes only data from the Bankscope database, considering financial and insurance companies.

a) In the case of the effective tax rate in the amount $16.7 \%$ for the Czech Republic.

b) Potential outflow of tax bases without considering whether it is possible to relocate business from the identified NACE sectors out of the Czech Republic.

c) Potential outflow of tax bases after considering whether it is possible to relocate business from the identified NACE sectors out of the Czech Republic. Non-relocated business is highlighted. 


\section{Ekonomie}

\section{Tab. 4: Overall Czech tax base after implementation of CССTB in other EU MS - part II}

\begin{tabular}{|c|c|c|c|c|}
\hline \multirow{3}{*}{ NACE } & \multicolumn{3}{|c|}{$\begin{array}{l}\text { Tax bases of the Czech subsidiaries of the parent companies } \\
\text { from the EU Member States except of the Czech Republic }\end{array}$} & \multirow{3}{*}{$\begin{array}{c}\begin{array}{c}\text { Expected } \\
\text { outflow tax } \\
\text { liability a }\end{array} \\
\text { in th. EUR }\end{array}$} \\
\hline & \multirow{2}{*}{$\begin{array}{c}\text { Current tax base } \\
\text { in th. EUR }\end{array}$} & \multicolumn{2}{|c|}{ Expected outflow of tax base } & \\
\hline & & $\%$ & in th. EUR & \\
\hline A & 3,806 & 8.03 & 3,640 & 608 \\
\hline B & 2,179 & - & - & - \\
\hline C & $1,227,361$ & 9.27 & 4,201 & 702 \\
\hline D & 142 & - & - & - \\
\hline$E$ & 6,291 & 0.04 & 19 & 3 \\
\hline $\mathbf{F}$ & 36,940 & - & - & - \\
\hline G & 50,989 & 0.06 & 29 & 5 \\
\hline $\mathbf{H}$ & 26,470 & - & - & - \\
\hline $\mathbf{I}$ & 41 & - & - & - \\
\hline $\mathbf{J}$ & 129,007 & 0.03 & 14 & 2 \\
\hline $\mathbf{K}^{1}$ & 594,105 & 1.97 & 894 & 150 \\
\hline $\mathrm{K}^{2}$ & $1,330,038$ & - & - & - \\
\hline $\mathbf{L}$ & 14,523 & - & - & - \\
\hline$M$ & $1,886,336$ & 78.32 & 35,481 & 5,925 \\
\hline $\mathbf{N}$ & 8,183 & 2.26 & 1,024 & 171 \\
\hline 0 & 706 & - & - & - \\
\hline $\mathbf{P}$ & - & - & - & - \\
\hline $\mathbf{Q}$ & - & - & - & - \\
\hline $\mathbf{R}$ & - & - & - & - \\
\hline $\mathrm{S}$ & - & - & - & - \\
\hline \multirow[t]{2}{*}{ Total $\mathbf{A}^{\mathrm{b}}$} & $5,317,117$ & $100 \%$ & 45,302 & 7,565 \\
\hline & $100 \%$ & & $0.85 \%$ & \\
\hline \multirow[t]{2}{*}{ Total B ${ }^{c}$} & $5,317,117$ & & 41,643 & 6,955 \\
\hline & $100 \%$ & & $0.78 \%$ & \\
\hline
\end{tabular}

Source: Own research and Amadeus and Bankscope databases

Note:

1) See explanation in Tab. 3 above.

2) NACE $K$ includes only data from the Amadeus database, not considering financial and insurance companies.

3) NACE K includes only data from the Bankscope database, not considering financial and insurance companies.

a) In the case of the effective tax rate in the amount $16.7 \%$ for the Czech Republic.

b) Potential outflow of tax bases without considering whether it is possible to relocate business from the identified NACE sectors out of the Czech Republic.

c) Potential outflow of tax bases after considering whether it is possible to relocate business from the identified NACE sectors out of the Czech Republic. Non-relocated business is highlighted. 
expected in order to achieve the possibility to enter into the CCCTB system for the whole group. In that case, the research identified the outflow of the tax bases in the amount of EUR 1,930,747,000 without considering the possibility to relocate the business activity out of the Czech Republic (situation A) and only EUR 184,092,000 with the consideration of relocation. Globally, the expected outflow of tax bases present the outflow of corporate tax liability in the amount of EUR $393,141,000$ in situation A and EUR 32,728,000 in situation B.

Tab. 4 above presents the results of the group of the other EU parent companies and their subsidiaries apart from the Czech Republic, generating the corporate tax base in the amount of EUR $5,317,117,000$ in the Czech Republic. In the case of this group, the research identified the potential outflow of tax bases in the amount of EUR 45,302,000 (i.e., $0.85 \%$ of the current tax bases allocated in the Czech Republic by the group) for situation $A$, where the largest outflow $(78.32 \%)$ is expected in NACE sector M - Professional, scientific and technical activities and then in NACE sector C - Manufacturing (9.27\%) and NACE sector A - Agriculture, forestry and fishing $(8.03 \%)$. The remaining NACE sectors $(\mathrm{N}, \mathrm{K}, \mathrm{J}, \mathrm{G}, \mathrm{E})$ represent a marginal portion of outflow. In situation $B$, the potential outflow would change fractionally from $0.85 \%$ to $0.78 \%$ of the current tax bases. In total, the expected outflow of tax bases represents the loss of corporate tax liability in the amount of EUR 7,565,000 (situation A) and EUR $6,955,000$ (situation B).

Tab. 5 below summarizes the potential outflow of tax bases for both groups. We expect outflow of 93 Czech subsidiaries and 18 Czech parent companies for situation A and 58 Czech subsidiaries and 12 Czech parent companies for situation B. After considering these two situations, we can conclude that the potential outflow of tax bases would be in the range of EUR $53,522,000$ up to EUR $471,755,000$ of the current tax base allocated in the Czech Republic by Czech subsidiaries (i.e., the range from $0.77 \%$ to $6.76 \%$ of current tax bases). Moreover, if the outflow of the tax bases of Czech parent companies is added, the overall outflow of tax bases would increase in the range of EUR $237,614,000$ up to $2,402,502,000$. This overall assumed outflow represents the loss of corporate tax liability in the range of EUR $39,583,000$ to EUR $400,706,000$ (i.e., $0.88 \%$ up to $8.85 \%$ of the corporate tax liability in 2011), where the lower limit symbolizes the result of situation $B$ and the upper limit the result of situation $A$.

Based on the research performed, we can conclude that the mandatory implementation of the CCCTB system in the Eurozone would have a negative impact on the tax bases generated in the Czech Republic and, subsequently, on Czech corporate tax revenues.

To validate the results, we decided to perform the sensitivity analysis and to take into account the transaction costs. We decided

\section{Tab. 5: Summary of results}

\begin{tabular}{|c|c|c|c|c|c|c|c|c|c|c|}
\hline \multirow{2}{*}{$\begin{array}{l}\text { Amadeus } \\
\text { and } \\
\text { Bankscope } \\
\text { databases }\end{array}$} & \multicolumn{2}{|c|}{ No. of companies } & \multicolumn{2}{|c|}{ No. of outflows } & \multirow{2}{*}{$\begin{array}{l}\text { Total tax } \\
\text { base in th. } \\
\text { EUR }\end{array}$} & \multicolumn{2}{|c|}{$\begin{array}{l}\text { Expected outflow of } \\
\text { tax bases in th. EUR }\end{array}$} & \multirow{2}{*}{$\begin{array}{l}\text { Corporate } \\
\text { tax liability } \\
\text { in th. EUR }\end{array}$} & \multicolumn{2}{|c|}{$\begin{array}{c}\text { Expected outflow } \\
\text { of tax liability in } \\
\text { th. EUR }\end{array}$} \\
\hline & CS & $\mathrm{CP}$ & CS & $\mathrm{CP}$ & & CS & $\mathrm{CP}$ & & CS & $\mathrm{CP}$ \\
\hline Total $A^{1}$ & 3,860 & 2,424 & 93 & 18 & $6,972,994$ & 471,755 & $1,930,747$ & $4,527,032$ & 78,271 & 322,435 \\
\hline$\%$ & & & & & 100 & 6.76 & - & 100 & 1.73 & 7.12 \\
\hline Total B ${ }^{2}$ & 3,860 & 2,424 & 58 & 12 & $6,972,994$ & 53,522 & 184,092 & $4,527,032$ & 8,840 & 30,743 \\
\hline$\%$ & & & & & 100 & 0.77 & - & 100 & 0.20 & 0.68 \\
\hline
\end{tabular}

Source: Own research and Amadeus and Bankscope databases

Note:

a) Based on the Czech tax statistics in 2011.

CS - Czech subsidiaries.

$\mathrm{CP}$ - Czech parent companies.

1) Results without considering the possibility to relocate business out of the Czech Republic.

2) Results with considering the possibility to relocate business out of the Czech Republic. 


\section{Tab. 6: Sensitivity analysis}

\begin{tabular}{|c|c|c|c|c|c|}
\hline \multirow{2}{*}{ Database } & \multirow{2}{*}{$\begin{array}{l}\text { Group } \\
\text { of the } \\
\text { companies }\end{array}$} & \multicolumn{3}{|c|}{ Changes caused by transaction costs } & \multirow{2}{*}{$\begin{array}{c}\text { Impact on overall } \\
\text { outflow of tax bases } \\
\text { and tax liability }\end{array}$} \\
\hline & & $1 \%$ & $5 \%$ & $10 \%$ & \\
\hline Amadeus & $\begin{array}{l}\text { Other EU parent } \\
\text { companies }\end{array}$ & none & 0 & $\begin{array}{c}726.26 \text { th. EUR } \\
(126.29 \text { th. EUR) }\end{array}$ & $\begin{array}{c}0.01 \% \text { decrease of } \\
\text { outflow and tax liability }\end{array}$ \\
\hline Amadeus & $\begin{array}{l}\text { Czech parent } \\
\text { companies }\end{array}$ & none & none & none & - \\
\hline Bankscope & $\begin{array}{l}\text { Czech parent } \\
\text { companies }\end{array}$ & none & none & none & - \\
\hline Bankscope & $\begin{array}{l}\text { Other EU parent } \\
\text { companies }^{1}\end{array}$ & - & - & - & - \\
\hline
\end{tabular}

Source: Own research and Amadeus and Bankscope databases

Note: 1) No outflow was identified in this group; therefore, no sensitivity analysis was performed.

to perform the analysis for the different levels of the transaction costs $-1 \%, 5 \%$ and $10 \%$ of the group tax burden based on the current situation - and analyze how those costs would change the potential outflow of tax bases and, subsequently, corporate tax revenues in the Czech Republic.

As seen in Tab. 6 above, the consideration of transaction costs would not significantly change the potential outflow of tax bases from the Czech Republic, as the research identified only one slight change in the case of transaction costs of $10 \%$ of a tax base, in the amount of EUR 726,000 (i.e., EUR 126,000 of tax liability). This slight change would have a positive impact on the overall outflow of tax bases, which would decrease the outflow from $6.76 \%$ to $6.75 \%$ (i.e., by $0.01 \%$ ) for situation A and from $0.77 \%$ to $0.76 \%$ for situation B. Furthermore, the research identified a change in the case of $5 \%$ transaction costs; however, the Czech subsidiary generates a negative tax base, which has zero effect on the potential outflow of tax bases from the Czech Republic.

Based on the sensitivity analysis performed, we can conclude that the impacts of the mandatory implementation of the CCCTB system in the Eurozone after considering transaction costs did not significantly change the previous results. The Czech Republic would lose corporate tax revenues in the range between $0.87 \%$ and $8.84 \%$ (i.e., a $0.01 \%$ change from the previous result) of the current corporate tax liability in 2011. Therefore, we can conclude that the mandatory implementation of the CCCTB system in the Eurozone would have a negative impact on the tax bases generated in the Czech Republic and, subsequently, on Czech corporate tax revenues.

\section{Conclusions and Discussion}

The aim of the paper was to research the impact of mandatory CCCTB implementation in the Eurozone on the tax bases and, consequently, on corporate tax revenues in the Czech Republic and to identify whether the implementation of the system will result in an outflow or inflow of the tax bases into the Czech Republic. The dataset used 2,424 parent companies with 3,860 subsidiaries from Amadeus and Bankscope databases that would qualify under the CCCTB system for the consolidation regime and group treatment.

The results of this research were reached under assumptions built on the idea of profit shifting and related real investments shifting with the aim to minimize the overall tax burden of the multinational group shown by existent literature. We assumed the outflow/inflow of tax bases from/into the Czech Republic depending on the rate of the effective tax rates in the Eurozone and the existence of at least one subsidiary of a Czech parent company in the Eurozone. Furthermore, we assume that the outflow of tax bases occurs if the group bears a lower tax burden after CCCTB implementation, with or without the consideration of the possibility to relocate business activities (situations $A$ and $B$ ). However, as already stated above, Avi-Yonah and Clausing (2007) mentions that the results 
of redistribution of tax bases depend on various future behavioral effects that are very difficult to predict. Therefore, the results of this research can be influenced by this fact.

Under the above-mentioned assumptions, no inflow was identified, only outflow - the overall outflow of 93 Czech subsidiaries and 18 Czech parent companies for situation $A$ and 58 Czech subsidiaries and 12 Czech parent companies for situation $\mathrm{B}$. The identified outflow would represent the loss of tax bases in the range between EUR 237,614,000 and EUR 2,402,502,000 - i.e., the loss of corporate tax revenues in the range between EUR 39,583,000 and EUR 400,706,000 (0.88\% up to $8.85 \%$ of corporate tax liability in the Czech Republic in 2011). The lower limit symbolizes the result of situation $B$ and the upper limit the result of situation $A$. The impacts of the mandatory implementation of the CCCTB system in the Eurozone on Czech tax bases and, subsequently, on Czech corporate tax revenues slightly changed after employing the different levels of transaction costs $(1 \%, 5 \%$ and $10 \%$ of the group tax burden based on the current situation) in the analysis. Employment decreased the outflow of tax bases and corporate tax liability by $0.01 \%$.

Based on this research, we can conclude that the mandatory implementation of the CCCTB system in the Eurozone will have a negative impact on the overall tax base allocated in the Czech Republic and, consequently, on corporate tax revenues. Under the formulated assumptions, we assume a loss between $0.87 \%$ and $8.84 \%$ of the current corporate tax liability in 2011. As the results shows, the way how to eliminate the outflow of tax bases from the Czech Republic in case of CCCTB implementation in Eurozone, might be the approximation of corporate tax. Comparable overall tax burden of the group under CCCTB system and Czech national taxation system would not motivate companies to shift to CCCTB jurisdictions and would therefore partially prevent base erosion.

Existing literature on CCCTB contains only a few empirical studies researching the impact of the introduction of the CCCTB on the budget revenues of EU Member States. However, none of studies takes into account the dynamic effects of the possible outflow/ inflow of tax bases, resulting in the changes of corporate tax liability caused by the implementation of CCCTB through enhanced cooperation (i.e., implementation not in all EU Member States, in our case in the Eurozone). The current literature does not reflect potential multinational groups' response to the CCCTB system. Only static revenue estimates based on the CCCTB's redistribution of corporate income tax collections among the participating Member States are performed in those studies.

The research presented in this paper goes further, as we merge the data from the Bankscope database, which has a significant impact on the final allocation of the tax bases among the EU Member states because it covers the financial sector, which is not included in the Amadeus database. Moreover, the dynamic factor inserted into the model considers reactions of multinational groups to the mandatory implementation of the CCCTB system in the Eurozone and takes into account different levels of transactional costs. In addition, the research presented in this paper goes beyond the current state of the art because we applied special allocation formulas the CCCTB proposal suggests for special industry sectors, which has not been done so far in any study.

Ultimately, it is necessary to mention that the aim of this research was to explore the impacts of CCCTB implementation in the Eurozone on tax revenues in the Czech Republic. However, there are also other impacts connected with the CССTB implementation that were not the subject of our research but are also important for the creation of the macroeconomic policy of the country: the impact on employment, job creation or GDP growth. Therefore, further research should be aimed at the exploration of those impacts on general macroeconomic indicators so that policy makers can obtain a complex picture of their policy creation.

The paper presents the results of the research within the GA CR project No. 13-21683S "The quantification of the impact of the introduction of the Common Consolidated Corporate Tax Base on the budget revenues in the Czech Republic." 


\section{References}

Amadeus database, Bureau Van Dijk.

Agúndez-García, A. (2006). The Delineation and Apportionment of an EU Consolidated Tax Base for Multi-jurisdictional Corporate Income Taxation: a Review of Issues and Options (Working Paper No. 9/2006). European Commission.

Avi-Yonah, R. S., \& Clausing, K. (2007). Reforming Corporate Taxation in a Global Economy: A Proposal to Adopt Formulary Apportionment (The Hamilton Project Discussion Paper).

Bankscope database, Bureau Van Dijk.

Bartelsman, E. J., \& Beetsma Roel, M. W. J. (2003). Why pay more? Corporate tax avoidance through transfer pricing in OECD countries. Journal of Public Economics, 87(9-10), 2225-2252. http://doi.org/10.1016/ S0047-2727(02)00018-X.

Bettendorf, L., Devereux, M. P., van der Horst, A., Loretz, S., \& De Mooij, R. A. (2010). Corporate tax harmonization in the EU. Economic Policy, 537-590.

Cline, R., Neubig, T., Phillips, A., Sanger, C., \& Walsh, A. (2010). Study on the economic and budgetary impact of the introduction of a Common Consolidated Corporate Tax Base in the European Union. Ernst \& Young LLP.

Cobham, A., \& Loretz, S. (2014). International distribution of the corporate tax base: Impact of different apportionment factors under unitary taxation. In 70th Annual Congress of the International Institute of Public Finance. Lugano, Switzerland.

Commission of European Communities. (1992). Report of the Committee of independent experts on company taxation. Luxembourg: Office for the official publication of the European Communities.

Danko, Z. (2012). Corporate tax harmonization in the European Union. In Conference proceedings: Crisis Aftermath: Economic Policy Changes in the EU and its Member States. (pp. 207-218). Szeged: University of Szeged.

David, P., \& Nerudová, D. (2008). Selected problems of value added tax application in the agricultural sector of the European Union internal market. Agricultural Economics, 54(1), $1-11$.
De Mooij, R. A., \& Ederveen, S. (2008). Corporate tax elasticities: a reader's guide to empirical findings. Oxford Review of Economic Policy, 24(4), 680-697. http://doi.org/10.1093/ oxrep/grn033.

Devereux, M., \& Loretz, S. (2008) Increased Efficiency through Consolidation and Formula Apportionment in the European Union? (Working Paper No. 12). Oxford: Oxford University, Centre for Business Taxation.

Dischinger, M. (2007). Profit Shifting by Multinationals: Indirect Evidence from European Micro Data (Munich Discussion Paper No. 2007-30). University of Munich.

Domonkos, T., Domonkos, Š., Dolinajcová, M., \& Grisáková, N. (2013). Effect of the Formulary Apportionment of the Common Consolidated Corporate Tax Base on the Tax Revenue in the Slovak Republic. Ekonomický časopis, 61(5), 453-467.

Dosser, D. (1973). British Taxation and the Common Market. London: Charles Knight.

Eberhartinger, E., \& Petutschnig, M. (2014). CCCTB - The Employment Factor Game (WU International Taxation Research Paper Series No. 2014 - 01).

Fuest, C., Hemmelgam, T., \& Ramb, F. (2007). How would the introduction of an EU-wide formula apportionment affect the distribution and size of the corporate tax base? An analysis based on German multinationals. International Tax and Public Finance, 14(5), 605-626. http://doi.org/10.1007/s10797-0069008-6.

Fuest, C., Spengel, C., Finke, K., Heckemeyer, J. H., \& Nusser, H. (2013). Profit Shifting and "Aggressive" Tax Planning by Multinational Firms: Issues and Options for Reform (Discussion Paper No. 13-078). ZEW Centre for European Economic Research.

Grubert, H., \& Slemrod, J. (1998). The effect of taxes on investment and income shifting into Puerto Rico. Review of Economics and Statistics, 80(3), 365-373. http://doi.org/10.1162/003465398557609.

Hines, J. R. Jr. (2010). Income misattribution under formula apportionment. European Economic Review, 54(1), 108-120. http://doi. org/10.1016/j.euroecorev.2009.08.011. 
Hitiris, T. (1994). European Community Economics (3rd ed.). London: Harvester Wheatsheaf.

Kolářová, E., \& Kuderová, E. (2015). Analysis of the Czech companies' departures to tax havens and their effect on the Czech Economy. In E. Pastuzsková, Z. Crhová, J. Vychytilová, B. Vytrhlíková, \& A. Knápková (Eds.), Proceedings of the 7th International Scientific Conference Firm and Performance of firms in science, education and practice (pp. 623-637).

Krchnivá, K. (2014). Comparison of European, Canadian and the U.S. formula apportionment on real data. In Enterprise and Competitive Environment - Conference Abstract Proceedings. Bučovice: Martin Stř̌̌ž Publishing.

Krchnivá, K., \& Nerudová, D. (2015). The Influence of Allocation Formula on Generation of Profit in Different Economy Sectors. Acta Universitatis Agriculturae et Silviculturae Mendelianae Brunensis, 63(6), 1961-1967. http://doi.org/10.11118/actaun201563061961.

Kubátová, K. (1998). Harmonizace daní v Evropské unii. Daně, (7-8), 2-7.

Lodin, S. O., \& Gammie, M. (2001). Home State Taxation. Amsterdam: IBFD.

Mackie-Mason, J. K., \& Gordon, R. H. (1997). How much do taxes discourage incorporation? Journal of Finance, 52(2), 477-505. http://doi.org/10.2307/2329487.

Mayer, S. (2009). Formulary Apportionment for the Internal Market. Amsterdam: IBFD.

McLure, Ch. E. (2008). Harmonizing corporate income taxes in the European community: Rational and implications. Tax Policy and the Economy, 22, 151-195.

Mintz, J. M. (2004). Corporate Tax Harmonization in Europe: It's All About Compliance. International Tax and Public Finance, 11(2), 221-234. http://doi.org/10.1023/ B:ITAX.0000011401.67566.14.

Mintz, J. (2008). Europe slowly lurches to a common consolidated corporate tax base: Issues at stake. In M. Lang et al. (Eds.), A Common Consolidated Corporate Tax Base for Europe (pp. 128-138). Alemanha: Springer.

Musgrave, P. B. (1967). Fiscal Harmonization in Common Markets. New York: Columbia University Press.
Nerudová, D. (2014). Harmonizace daňových systémů zemí Evropské unie (4th ed.). Praha: Wolters Kluwer ČR.

Nerudová, D., \& Solilová, V. (2014). Missing data and its impact on the CCCTB determination. Procedia Economics and Finance, 12, 462-471. https://doi.org/10.1016/ S2212-5671(14)00368-2.

Nerudová, D. (2012). Common Consolidated Corporate Tax base: Sharing the Tax Base under Formulary Apportionment. In D. Stavárek, \& P. Vodová (Eds.), Proceedings of the 13th international conference on finance and banking (pp. 279-288).

Nerudová, D., \& Solilová, V. (2015). Quantification of the impact on the total corporate tax basis in the Czech Republic caused by the CCCTB implementation in EU28. Politická ekonomie, 63(4), 456-773.

Pethig, R., \& Wagener, A. (2003). Profit Tax Competition and Formula Apportionment (CESifo Working Paper No. 1011).

Petutschnig, M. (2010). Common Consolidated Corporate Tax Base: Effects of Formulary Apportionment on Corporate Group Entities (WU International Taxation Research Paper Series No. 2012-04).

Pirvu, D., Banica, L., \& Hagiu, A. (2011). Implications of the introduction of the Common Consolidated Corporate Tax Base for tax revenues in Romania. Financial theory and practice, 35(2), 197-215.

Roggeman, A., Verleyen, I., Van Cauwenberge, P., \& Coppens, C. (2012). An empirical investigation into the design of an EU apportionment formula related to profit generating factors. Transformations in Business \& Economics, 11(3(27)), 36-56.

Simon, J. (2000). Can We Harmonise Our Views on European Tax Harmonisation? Bulletin for international fiscal documentation, 54(6), 263-269.

Solilová, V., \& Nerudová, D. (2016). Implementation of Common Consolidated Corporate Tax Base and its Implications for Non-participating Country: A Case Study for the Czech Republic. Ekonomický časopis, 64(3), 282-298.

Spengel, C., Endres, D., Finke, K., \& Heckemeyer, J. (2014). Effective Tax Levels 


\section{Ekonomie}

Using the Devereux/Griffith Methodology. EU Commission project No. TAXUD/2013/CC/120, Manheim: ZEW.

Tan, J. H. D. (2010). Unitary Formulary Apportionment as a Solution to the Conundrum of Source. New York University School of Law.

Trandafir, A. (2011). Common Consolidated Corporate Tax Base, a new measure to remove tax competition distortions in the EU. Economy Transdisciplinary Cognition, 14(1), 310-317.

Van Der Horst, A., Bettendorf, L., \& RojasRomagosa, H. (2007). Will corporate tax consolidation improve efficiency in the EU? (CPB Documents 141). CPB Netherlands Bureau for Economic Policy Analysis.

Weiner, J. M. (2005). Formulary Apportionment and Group Taxation in the EU: Insights from the United States and Canada.
Taxation papers (Working Paper No. 8). DG Taxation and Customs Union, European Commission.

Prof. Ing. Danuše Nerudová, Ph.D. Mendel University in Brno

Faculty of Business and Economics Department of Accounting and Taxation Czech Republic d.nerudova@seznam.cz

Ing. Veronika Solilová, Ph.D. Mendel University in Brno

Faculty of Business and Economics Department of Accounting and Taxation Czech Republic ritve@email.cz 


\section{Abstract}

\section{MANDATORY CCCTB IMPLEMENTATION IN THE EUROZONE AND ITS IMPACT ON CORPORATE TAX REVENUES IN THE CZECH REPUBLIC}

\section{Danuše Nerudová, Veronika Solilová}

The European Commission has been attempting to coordinate the corporate taxation systems of the EU Member States since 1962. One of the most ambitious projects in the history of the harmonization effort was introduced on 16 March 2011, when the European Commission published, after more than ten years of work, the text of the CCCTB Directive proposal. The directive proposal suggests the consolidation regime and the allocation formula with three equally weighted factors sales, labour and assets, i.e. the consolidated tax base should be shared among the members of the group based on those micro factors. That tax-sharing mechanism as a new allocation rule has raised much discussion and will definitely have an impact on EU Member States' budgets. The aim of the paper is to research the impact of mandatory CCCTB implementation in the Eurozone on tax bases in the Czech Republic and consequently on Czech corporate tax revenues, and to identify whether the implementation of the system in the Eurozone will result in the outflow or inflow of tax bases from/to the Czech Republic. The research is based on empirical data from the Amadeus and Bankscope databases covering 2,424 parent companies with 3,860 Czech subsidiaries. In order to verify the results of the research, a sensitivity analysis was also performed. The research revealed that mandatory implementation of the CCCTB system in the Eurozone would have negative impact on the tax bases currently generated and located in the Czech Republic. As a result of this fact, the Czech Republic would lose between $0.87 \%$ and $8.84 \%$ of the corporate tax liability recorded in 2011.

Key Words: CCCTB, group, tax base, tax revenue, Czech Republic, Eurozone.

JEL Classification: H25, K22.

DOI: 10.15240/tul/001/2018-1-001 